\title{
Pendampingan Peningkatan Teknologi Proses Agroindustri Produk Lokal (Pengeringan Gabah) Di Pekon Mataram
}

\author{
Indriyani ${ }^{1}$, Ari Beni Santoso ${ }^{1}$, Yuliana Yamin $^{1}$, Nuzleha ${ }^{1}$ \\ Universitas Sang Bumi Ruwa Jurai \\ indriyani220403@gmail.com, santosoaribeni@gmail.com, yuliyamin67@gmail.com,nuzlehajar@gmail.com
}

\begin{abstract}
Abstrak
Teknologi pasca panen yang telah diterapkan di Pekon Mataram adalah dengan metode yang masih konvensional yaitu cara pengeringan gabah dengan menjemur di atas tanah kering, di atas plastik, di atas semen dan di atas plastik yang diletakkan di atas semen dan tidak ada proses pengerinngan dengan oven dalam box dryer. Pengeringan gabah masih berkapasitas kecil di bawah 0,5 ton per hari. Metode pengabdian diawali dengan memberikan penyuluhan/sosialisasi di Balai Pekon Mataram kepada Tiga Kelompok Tani "Makmur, Sejahtera, Jaya" yang berjumlah 15 anggota. Dilanjutkan dengan bimbingan teknologi pasca panen yang baik sehingga dengan mengukur kadar air gabah kering yang layak untuk diolah/digiling melalui mesin penggilingan padi kapasitas kecil. Para anggota dalam Kelompok Tani "Makmur, Sejahtera, dan Jaya" sekitar $30 \%$ [delapan puluh persen atau 12 orang dari 15 orang) memahami pentingnya proses pengeringan dengan kadar air hanya sekitar $20-25 \%$ pada gabah yang dikeringkan untuk diproses penggilingan, sehingga akan menghasilkan rasa dan kualitas beras yang tinggi untuk dijual kepada konsumen. Tiga orang akan mengikuti prosedur pengeringan gabah yang telah diberikan pendampingan.
\end{abstract}

Kata Kunci : Teknologi Pasca Panen, Pengeringan, Penggilingan, Kadar Air, Oven, Box Dyer

\begin{abstract}
Post-harvest technology that has been applied at Pekon Mataram is a method that is still conventional, namely the method of drying grain by drying on dry soil, on plastic, on cement and on plastic placed on cement and there is no drying process with an oven in the oven. box dryer. Drying of grain is still a small capacity of less than 0.5 tons per day. The service method begins by providing counseling/socialization at the Mataram Village Hall to the Three Farmer Groups "Prosperous, Prosperous, Jaya" totaling 15 members. Followed by good post-harvest technology guidance so that by measuring the moisture content of dry grain that is suitable for processing/milling through a small capacity rice milling machine. The members in the "Makmur, Sejahtera, and Jaya" Farmers Group about 30\% [eighty percent or 12 people out of 15 people] understood and was the importance of the drying process with a moisture content of only about $20-25 \%$ on grain that was dried for milling, so that it will produce high taste and quality rice for sale to consumers. Three people will follow the grain drying procedure that has been given assistance.
\end{abstract}

Keywords: Post-Harvest Technology, Drying, Milling, Moisture Content, Oven, Box Dyer 


\section{PENDAHULUAN}

Rendahnya produktifitas dan nilai tambah produk pertanian disebabkan oleh teknolgi pengolahan produk pertanian yang belum maksimal. Proses pengolahan memerlukan investasiu dan teknologi yang lebih modern dengan peningkatan nilai tambah produk pertanian. Rendahnya tingkat utilisasi industri hasil pertanian.

Beras dan rentannya ketahanan pangan di tingkat rumah tangga masih merupakan masalah yang masih tinggi ketergantungannya. Tekanan terhadap peningkatan produksi padi semakin tinngi pula. Kebutuhan beras dalam negeri mencapai 0- $5 \%$. Palawija dan sumber protein yang berasal dari daging, telur dan susu, namun tingkat konsumsinya masih rendah. Tingkat konsumsi energi mencapai sebesar 3.211 kkal sudah melebihi skor pola pangan harapan (PPH) sebesar 2.200 kkal. Tingkat konsumsi energi tersebut baru mencapai skor 66,7 kkal dari skor ideal sebesar 100,kkal karena ketergantungan yang tinggi terhadap konsumsi karbohidrat terutama beras dan masih sangat kurang pada pangan hewani, sayur dan buah. Konsumsi sumber energi dari beras hanya dibutuhkan sebesar $1.100 \mathrm{kkal}$, namun tingkat konsumsinya mencapai $2.104 \mathrm{kkal}$. Tingkat konsumsi pangan hewani yang dibutuhkan sebesar 264 kkal, hanya mencapai 76 kkal. Pola konsumsi seperti ini kurang mendukung pengembangan kualitas sumberdaya manusia.

Di pedesaan dinilai sangat strategis peningkatan nilai tambah produk pertaniann agroindustri. Strategi peningkatan nilai tambah menurut Parcel et al. (2010) dapat dilakukan melalui 2 cara yaitu: 1) menjaring nilai (capturing value) dan 2) menciptakan nilai (creating value). Anderson dan Hal (2008), merinci bahwa peningkatan nilai tambah melalui kedua strategi tersebut merupakan fungsi dari mutu (quality), fungsi (functionality), bentuk (form), tempat (place), waktu (time) dan kemudahan mendapatkan (ease of possession). Peningkatan nilai tambah produk pertanian merupakan peningkatan pendapatan yang dapat dilakukan melalui: budidaya tanaman untuk pasar tertentu/khusus, perubahan bentuk produk dari aslinya sebelum dipasarkan, perubahan pengemasan produk, perubahan cara memasarkan produk serta mengembangkan unit usaha baru (Born dan Bachmann, 2006) dalam Jurnal Teknologi Industri Pertanian.

\section{METODE PELAKSANAAN}

Metode yang digunakan dalam kegiatan pelatihan ini sebagai berikut: 1) Metode ceramah digunakan oleh pemateri unuk menjelaskan materi yang berkaitan dengan materi pengelolaan keuangan koperasi, 2) Metode diskusi digunakan untuk memperdalam materi bahasan baik bentuk tanya jawab secara perorangan maupun perwakilan peserta, 3) Metode pemberian studi kasus pemyusun laporan keuangan sederhana untuk KSU.

Materi penyusunan laporan keuangan bagi KSU Munyai Mekhawan berisi formulir atau daftar yang digunakan adalah sebagai berikut: 1) Rencan aAnggaranBiaya, 2) Buku Bank, 3) BukuBesar, 4) BukuPembantu Advance, 5) BukuPembantuBiaya, 6) Buku Kas Kecil (jika ada), 7) Rekonsiliasi Bank.

Hasil kegiatan ini diharapkan dapat memberikan kontribusi pengetahuan para peserta untuk dapat menyusun laporan keuangan koperasi dengan baik. Lembaga yang menangani kegiatan pengabdian ini adalah lembaga Pengabdian Masyarakat Universitas Sang Bumi Ruwai Jurai dalam rangka mewujudkan Tridharma Perguruan Tinggi. 


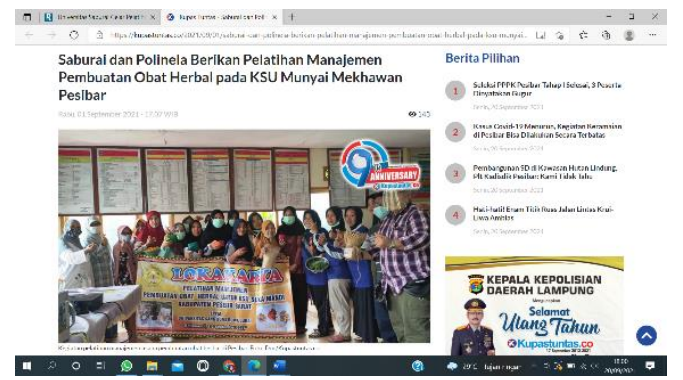

Gambar 1. Foto Publikasi Kegiatan Pengabdian Kepada Masyarakat di Media Online Kupas Tuntas

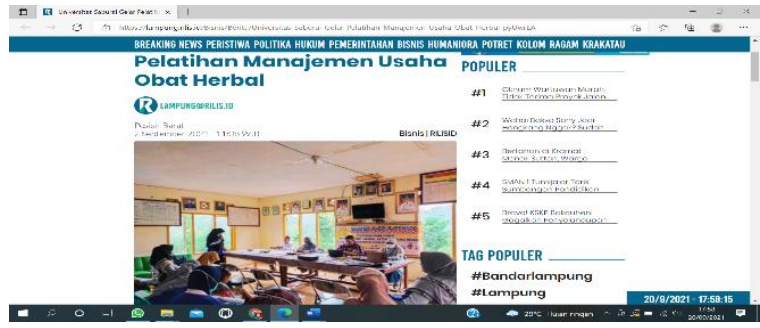

Gambar 2.Publikasi Kegiatan Pengabdian Kepada Masyarakat di Media Online Lampung Rilis

\section{HASIL DAN PEMBAHASAN}

Kegiatan ini merupakan pengabdian dalam rangka menumbuhkan minat dan kesadaran para anggota KSU Munyai Mekhawan Pekon Labuhan Mandi, Pesisir Barat, khususnya para pengurus KSU Munyai Mekhawan untuk dapat mengelola koperasi secara profesional dengan membuat pembukuan sederhana serta meningkatkan penjualan produk pengolahan hernal (rempah) baik secara offline maupun online (daring) dalam upaya pemberdayaan ekonomi keluarga pada masyarakat Pesisir di Masa Covid-19.

Pelatihan ini diikuti oleh peserta dari KSU Munyai Mekhawan, Pekon Labuhan Mandi, Pesisir Barat. Peserta berasal dari pengurus keuangan yang terkait keuangan, laporan keuangan, dan pengurus yang terkait akses ke rekening koran di Bank.

Berdasarkan hasil survey dan konsultasi dengan ketua koperasi maka pada tanggal 21-22 Oktober 2021 telah dilaksanakan kegiatan sosialisasi dan pelatihan keuangan laporan keuangan koperasi, dalam meningkatkan pemahaman para pengelola koperasi dalam membuat laporan keuangan KSU Munyai Mekhawan, Pekon Labuhan Mandi, Pesisir Barat

Peserta pelatihan pada tahap awal (sesi pagi), diberikan materi tentang laporan keuangan koperasi berupa Rencana Anggaran Biaya, Buku Bank, dan Buku Besar. Peserta pada tahap kedua (sesi siang) diberikan pelatihan penyusunan laporan keuangan, Buku Pembantu Advance, Buku Pembantu Biaya, Buku Kas Kecil (jikaada), dan Rekonsiliasi Bank. Setelah itu para peserta diajak berdialog dengan tanya jawab menyangkut materi yang telah disampaikan. Sedangkan hasil evaluasi yang telah dilakukan untuk mengukur tingkat keberhasilan program kegiatan pengabdian ini, dapat dijabarkan sebagai berikut: 1)Pengetahuan serta serta minat dari para pengelola usaha KSU Munyai Mekhawan, Pekon Labuhan Mandi, Pesisir Barat.tentang materi laporan keuangan, 2) Tingkat pengetahuan dan pemahaman para pengelola usaha KSU Munyai Mekhawan, Pekon Labuhan Mandi, Pesisir Barat diukur dengan partisipasi yang berkembang dalam tanya jawab dan praktek ilustrasi pelatihan perhitungan contoh soal kasus penyusunan laporan keuangan koperasi, 3) Berdasarkan data di lapangan nampak bahwa para peserta kegiatan pelatihan sangat memahami 
penjelasan materi yang disampaikan. Hal ini dibuktikan dengan berbagai macam pertanyaan yang diajukan serta diskusi.

\section{KESIMPULAN}

Berdasarkan kegiatan Pengabdian kepada Masyarakat di KSU Munyai Mekhawan tersebut dapat ditarik kesimpulan bahwa pencatatan transaksi keuangan yang dilakukan sampai saat ini hanya pencatatan terhadap kas masuk dan kas keluar dari hasil penjualan dan pembelian. Prosedur pencatatan juga belum dilakukan secara baik, dimana bukti transaksi belum diarsipkan secara terstruktur, sehingga dikhawatirkan mengalami kesulitan bila akan dibutuhkan. Sedangkan kendala dalam penyusunan laporan keuangan sampai saat ini adalah belum adanya sumberdaya manusia yang mampu menyusun laporan keuangan, dikarenakan SDM yang tersedia memiliki keterbatasan pendidikan, dengan latar pendidikan lulusan SD.

Pelatihan Penyusunan Laporan Keuangan berjalan sangat aktif dan komunikatif. Awal pelatihan diberikan permainan untuk meningkatkan motivasi terhadap peserta yang merupakan pengurus yang terkait dengan keuangan koperasi. Materi diberikan mengenai pemahaman laporan keuangan dan tujuan adanya laporan keuangan agar peserta mengetahui pentingnya laporan keuangan. Setelah itu diberikan materi yang yang terkait kasus laporan keuangan yang terdiri dari : Rencana Anggaran Biaya, Buku Bank, Buku Besar, Buku Pembantu Advance, Buku Pembantu Biaya, Buku Kas Kecil (jika ada), dan Rekonsiliasi Bank. Alhamdulillah pada pelaksanaannya para peserta memahami materi terlihat dengan antusiasnya peserta dalam berdiskusi dan pengerjaan kasus.

\section{Saran}

Berdasarkan Pengabdian yang dilakukan, beberapa saran yang diharapkan dapat bermanfaat adalah sebagai berikut : 1) KSU Munyai Mekhawandiharapkan melakukan pencatatan secara lengkap mengenai aktivitas operasinya, melakukan siklus akuntansi secara lengkap melakukan klasifikasipos-pos laporan keuangan yaitu dengan melakukan identifikasi, pengakuan, pengukuran, pencatatan, penyajian, dan pengungkapan laporan keuangansesuai standar yang berlaku; 2) KSU Munyai Mekhawan diharapkan dapat membuat laporan keuangan lengkap secara benar, meliputi Laporan Laba Rugi, laporan perubahan Modal, laporan Neraca, Laporan Arus Kas, dan catatan atas laporan keuangan; 3) Peningkatan sarana dan prasarana yang mendukung penyusunan laporan keuangan. Misalnya dengan penyediaan komputer dan aplikasi pendukungnya untuk mempermudah pencatatan keuangan yang akurat dan efisien; 4) Koperasi melakukan peningkatan dan pengembangan pendidikan anggotan melalui pelaksanaan pelatihan dan penyuluhan penyusunan laporan keuangan koperasi yang dilakukan secara rutin dan berkala. Untuk meningkatkan pemahaman penyusunan laporan keuangan serta kegiatan penyusunan laporan keuangan bisa terus berjalan; 5) Adanya pengawasan dari anggota koperasi, pihak investor, masyarakat, dan pemerintah agar penyusunan laporan keuangan sesuai aturan yang berlaku umum dan transparan. 


\section{UCAPAN TERIMA KASIH}

Puji syukur kami panjatkan kehadirat Tuhan Yang Maha Esa atas limpahan rahmat dan kasih sayang-Nya.Tidak lupa pula shalawat dan salam senantiasa tercurahkan bagi Rasulullah Saw. yang telah membawa manusia dari zaman kegelapan menuju zaman terang benderang. Penyusunan Laporan Pelaksanaan Kegiatan Pengabdian kepada Masyarakat (PkM) ini dapat berjalan dengan baik dengan adanya kerjasama dari berbagai pihak mulai dari Universitas Sang Bumi Ruwa Jurai , aparat kecamatan, aparat kelurahan, hingga masyarakat setempat. Akhirnya kami berharap semoga apa yang telah kami laksanakan dapat bermanfaat bagi masyarakat secara umum dan lebih khususnya bagi kami sebagai wahana pembelajaran mental dan cara hidup bermasyarakat.

\section{DAFTAR PUSTAKA}

Fees Warren. 2014. Accounting Pengantar Akuntansi. Jakarta: Salemba Empat.

Harahap, Sofyan Syafri. 2018. “Analisis Kritis Atas Laporan Keuangan”. Jakarta: RajaGrafindo Persada

Hendriksen dan Brenda. 2014 . Teori Akunting. Interaksara: Tangerang.

Ikatan Akuntansi Indonesia,2018, Standar Akuntansi Keuangan, PSAK No.1: Penyajian Laporan Keuangan .Jakarta : Salemba Empat.

Kusnadi, Hendar.2017, Ekonomi Koperasi Edisi 2. Jakarta: Universitas Indonesia.

Munawir.2014, Analisa Laporan Keuangan Cet. 15. Yogyakarta : Liberty.

Riastuti, Aryani. 2008. Analisis pemasaran emping melinjo di kabupaten Sragen. Surakata : Universitas Sebelas Maret.

Sukarman. 2002. Pengelolaan dan Penanganan Benih Aneka Tanaman Perkebunan : Kasus Jambu Mete, Makadamia, Kemiri, Melinjo, dan Tamarin. Jurnal Perseptif : Review Penelitian Tanaman Industri Volume 1 Nomor 2. Badan Penelitian dan Pengembangan Pertanian Pusat Penelitian dan Pengembangan Perkebunan. Jakarta

Sunanto, H. 1991. Budidaya Melinjo dan Usaha Produksi Emping. Kanisius. Yogyakarta.

Syamsudin,.2015, Analisis Perkembangan Usaha Perkembangan Usaha Emping Melinjo Yang Memperoleh Kredit dari Koperasi Tani Rejo Kecamatan Limpung, Kabupaten Batang. Semarang : Universitas Diponegoro.

UNESA. 2000. Pedoman Penulisan Artikel Jurnal, Surabaya: Lembaga Penelitian Universitas Negeri Surabaya. 